\title{
MODEL FORMS FOR GIRLS' APPAREL
}

\section{COMMERCIAL STANDARD CS158-49}

Effective Date for New Production From December 1, 1949

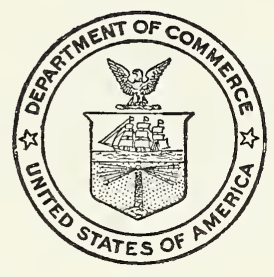

A RECORDED VOLUNTARY STANDARD

OF THE TRADE

UNITED STATES DEPARTMENT OF COMMERCE CHARLES SAWYER, Secretary 


\section{COMMODITY STANDARDS}

Simplified Practice Recommendations and Commercial Standards are developed by manufacturers, distributors, and users in cooperation with the Commodity Standards Division of the National Bureau of Standards. The purpose of Simplified Practice Recommendations is to eliminate avoidable waste through the establishment of standards of practice for stock sizes and varieties of specific commodities that currently are in general production and demand. The purpose of Commercial Standards is to establish standard methods of test, rating, certification, and labeling of commodities, and to provide uniform bases for fair competition.

The adoption and use of a Simplified Practice Recommendation or Commercial Standard is voluntary. However, when reference to a Commercial Standard is made in contracts, labels, invoices, or advertising literature, the provisions of the standard are enforceable through usual legal channels as a part of the sales contract.

A Simplified Practice Recommendation or Commercial Standard originates with the proponent industry. The sponsors may be manufacturers, distributors, or users of the specific product. One of these three elements of industry submits to the Commodity Standards Division the necessary data to be used as the basis for developing a standard of practice. The Division, by means of assembled conferences or letter referenda, or both, assists the sponsor group in arriving at a tentative standard of practice and thereafter refers it to the other elements of the same industry for approval or for constructive criticism that will be helpful in making any necessary adjustments. The regular procedure of the Division assures continuous servicing of each effective Simplified Practice Recommendation and Commercial Standard, through review and revision, whenever, in the opinion of the industry, changing conditions warrant such action. Simplified Practice Recommendations and Commercial Standards are printed and made available by the Department of Commerce through the Government Printing Office.

\section{COMMERCIAL STANDARD FOR MODEL FORMS FOR} GIRLS' APPAREL

On June 28, 1948, a recommended commercial standard for model forms for girls' apparel was circulated to manufacturers, distributors, and users for written acceptance. This standard was proposed by the Limited Price Variety Stores Association, Inc., and the Mail Order Association of America, and adjusted in the light of comments from manufacturers and users of model forms. Those concerned have since accepted and approved the standard as shown herein.

Project Manager: Mansfield Lonie, Commodity Standards Division, National Bureau of Standards.

Technical Adviser: W. D. ApPEL, Organic and Fibrous Materials Division, National Bureau of Standards. 
for

\section{MODEL FORMS FOR GIRLS' APPAREL}

Note.-This commercial standard is based on the measurements, size-to-size intervals, and size designations in Commercial Standard CS153-48, Body Measurements for the Sizing of Apparel for Girls (for the Knit Underwear Industry). The exact detailed relationships between the body and form measurements for a given size are shown herein in table 4.

\section{PURPOSE}

1. The purpose of this standard is to provide a standard classification, size designations, and measurements for commercial model forms for the sizing of girls' ready-to-wear apparel.

\section{$\mathrm{SCOPE}^{1}$}

2. This standard covers:

(a) Types of forms.

(1) Dress or coat.

(2) Sports-bifurcated and suspended, in knee or ankle length.

(b) Methods of measuring forms.

(1) General.

(2) Girth measurements.

(3) Width measurements.

(4) Length measurements.

(5) Vertical measurements.

(c) Classification, size designations, and measurements.

(1) Girls' model forms, sizes 7 to 14 .

(d) Recommended methods of identification.

\section{METHODS OF MEASURING MODEL FORMS}

3. General.-Measurements are taken to the nearest $1 / 8$ inch.

4. Girth measurements.

(a) Chest.-Measured horizontally around forms, C, at a distance, SS, paragraph $6(\mathrm{~d})$, above waistline. Figures 1 and $2 .^{2}$

${ }_{1}^{1}$ This is one of a coordinated series of standards that will cover classifications from toddlers to teen-age boys and girls.

2 This chest measurement will not necessarily check with the final form measurement, because the armhole plates or extensions on the finished form may cover the upper point of the SS measurement. This identifies the location on the form at which chest measurements were taken on girls. 
(b) Waist.-Measured around forms over tape. W, figures 1 and 2.

(c) Hip.-Measured around forms, $\mathrm{H}$, at a distance, D, paragraph 6 (e), below waistline. Figures 1 and 2.

(d) Vertical trunk.-Measured around sports forms through the middle of the shoulder seam and the crotch. V, figure 2 .

(e) Thigh.-Measured horizontally around leg of sports form, close up to the crotch. T, figure 2 .

(f). Knee.-Measured around leg of sports form. K, figure 2.

(g) Calf.-Measured around leg of sports form. F, figure 3.

(h) Neckline.-Measured"around neck seam. N, figures 1 and 2.

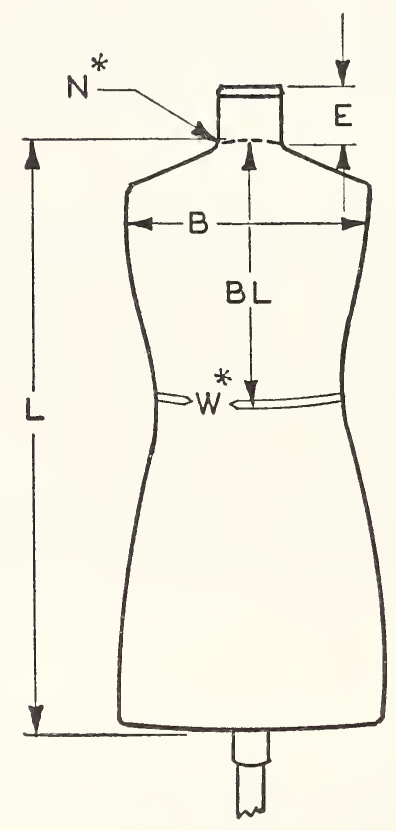

BACK VIEW

*

MEASUREMENTS TAKEN AROUND FORM

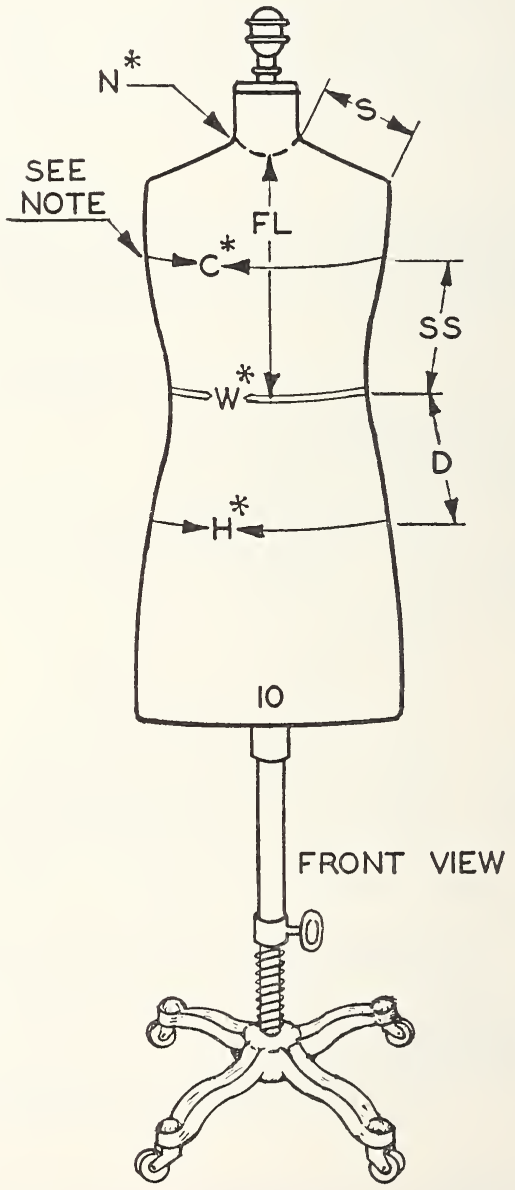

Figure 1. Dress or coat form.

NoтE. This chest measurement will not necessarily check with the final form measurement because the armhole plates or extensions on the finished form may cover the upper point of the SS measurement. This identifies the location on the form at which chest measurements were taken on girls. 


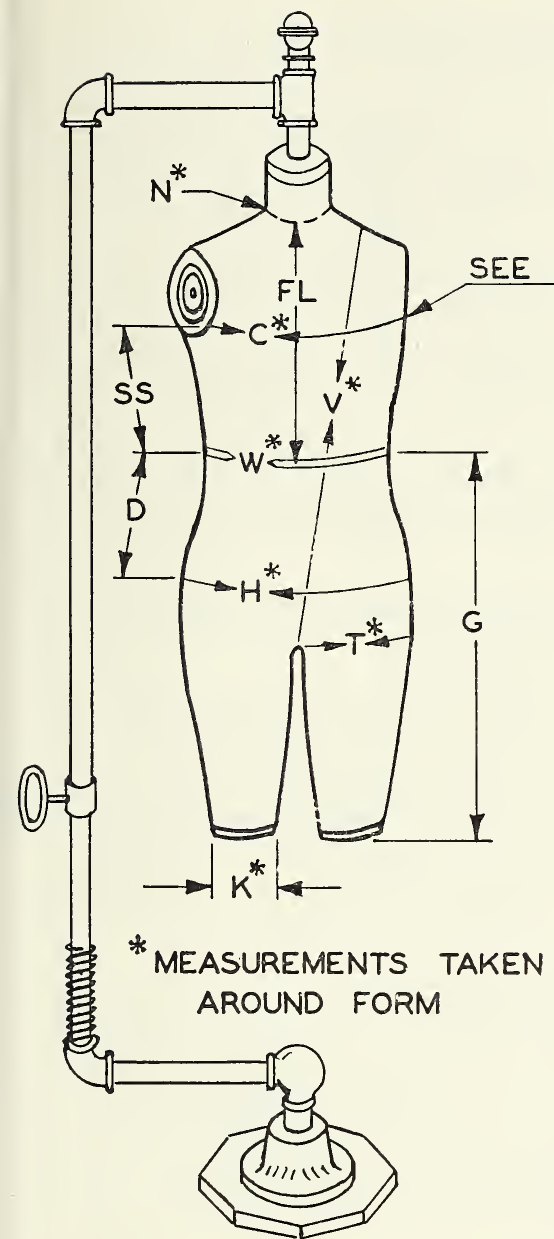

Figure 2. Sports form-knee length (front view).

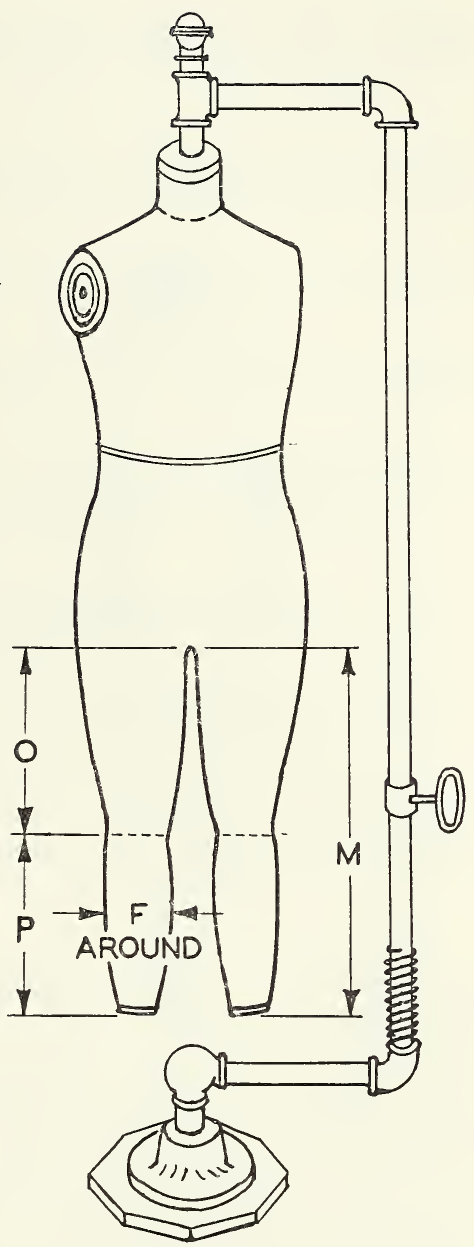

Figure 3. Sports form-ankle length (front view).

Note. This chest measurement will not necessarily check with the final form measurement because the armhole plates or extensions on the finished form may cover the upper point of the SS measurement. This identifies the location on the form at which chest measurements were taken on girls.

5. Width measurements.

(a) Shoulder.-Measured along shoulder seam from neck seam to armhole edge. S, figures 1 and 5 .

(b) Cross-back. - Measured across back, from armhole edge to armhole edge, at depth halfway between neck seam and level of chest girth measurement. B, figures 1 and 5 .

6. Length measurements.

(a) Neck extension.-Measured from neck edge of shoulder seam to upper edge of the extension. E, figures 1 and 5. 


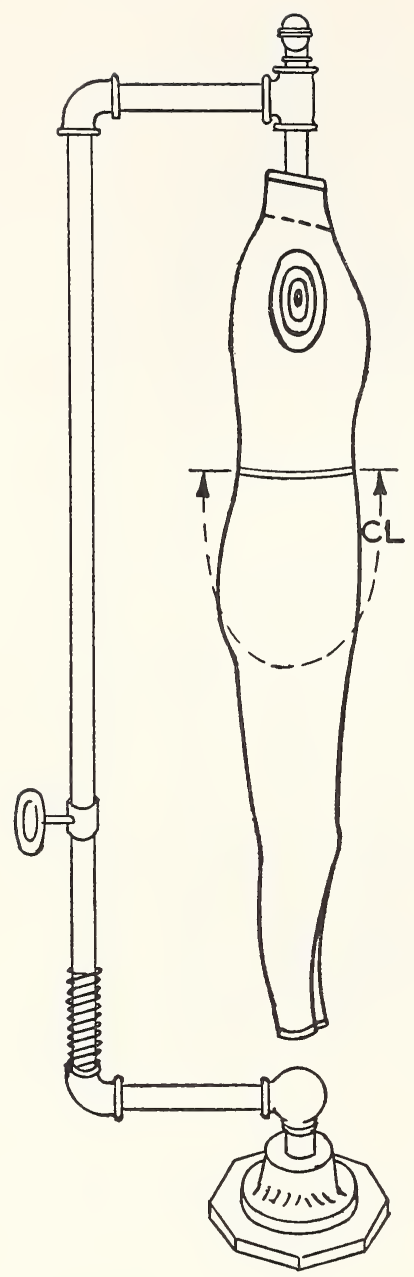

Figure 4. Sports form-ankle length (side view).

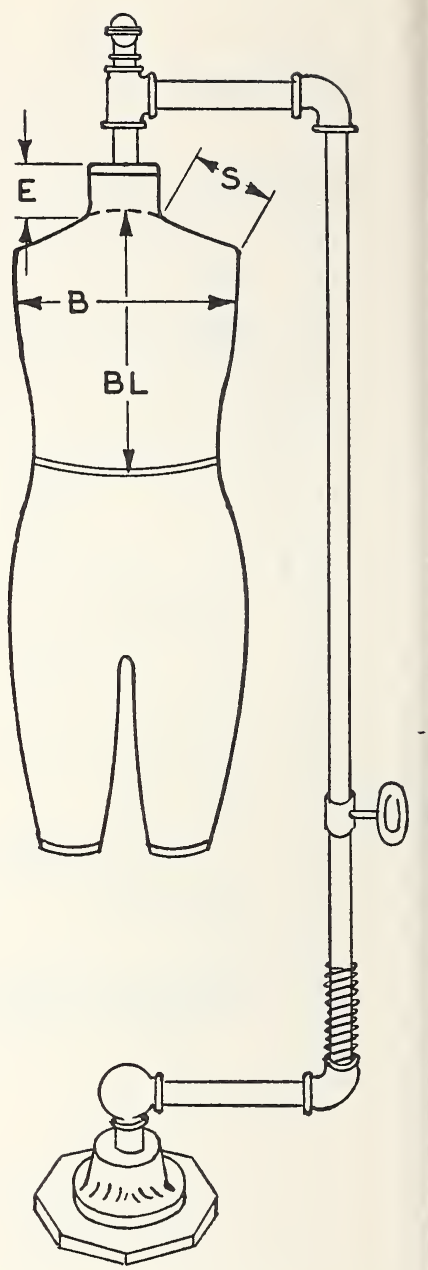

Figure 5. Sports form-knee length (back view).

(b) Back waist.-Measured from neckline, along center back seam, to the center of the tape at waistline. BL, figures 1 and 5 .

(c) Front waist.-Measured from neckline, along center front seam, to the center of the tape at the waistline. FL, figures 1 and 2 .

(d) Waist to armscye.-Measured from center of the tape at waistline, along side seam toward armscye. SS, figures 1 and 2.

(e) Waist to hip.-Measured from center of the tape at waistline, along the side seam toward hip. D, figures 1 and 2 .

(f) Total crotch.-Measured from waistline of sports form at center front through crotch to waistline at center back. CL, figure 4. 
(g) Total form length.-Measured from neckline, along center back seam, to the bottom of the form. L, figure 1 .

7. Vertical measurements.

(a) Waist to knee.-Measured vertically from a point level with the waistline of the sports form to a point level with the knee. G, figure 2.

(b) Crotch to knee.-Measured from the crotch of the sports form to a point level with the knee. O, figure 3 .

(c) Crotch to ankle.-Measured from the crotch of the sports form to a point level with the bottom of the form. M, figure 3.

(d) Knee to ankle.-Measured from a point level with the knee of the sports form to the bottom of the form. P, figure 3 .

\section{SIZE DESIGNATIONS AND CORRESPONDING MEASUREMENTS}

8. Dress form.-The size designations and corresponding form measurements are given in table 1.

9. Coat form.-The size designations and corresponding form measurements are given in table 2.

10. Sports form.-The size designations and corresponding form measurements are given in table 3.

TABLE 1. Girls' dress form ${ }^{1}$ measurements

\begin{tabular}{|c|c|c|c|c|c|c|}
\hline \multirow[b]{2}{*}{ Name of measurement } & \multicolumn{6}{|c|}{$\mathrm{S} \mathrm{I} \mathrm{Z} \mathrm{E} \mathrm{S}$} \\
\hline & 7 & 8 & 9 & 10 & 12 & 14 \\
\hline \multicolumn{7}{|c|}{ GIRTH MEASUREMENTS } \\
\hline $\begin{array}{l}\text { Chest } \\
\text { Waist-1.2. (W) } \\
\text { Hip } \\
\text { Neckline. }\end{array}$ & $\begin{array}{c}\text { Inches } \\
271 / 2 \\
23 \\
28 \\
113 / 8\end{array}$ & $\begin{array}{c}\text { Inches } \\
281 / 2 \\
231 / 2 \\
29 \\
113 / 4\end{array}$ & \begin{tabular}{|c|} 
Inches \\
$291 / 2$ \\
24 \\
30 \\
$121 / 8$
\end{tabular} & $\begin{array}{r}\text { Inches } \\
301 / 2 \\
241 / 2 \\
311 / 2 \\
121 / 2\end{array}$ & $\begin{array}{c}\text { Inches } \\
32 \\
251 / 2 \\
331 / 2 \\
13\end{array}$ & $\begin{array}{r}\text { Inches } \\
331 / 2 \\
261 / 2 \\
351 / 2 \\
131 / 2\end{array}$ \\
\hline
\end{tabular}

WIDTH MEASUREMENTS

\begin{tabular}{|c|c|c|c|c|c|c|}
\hline 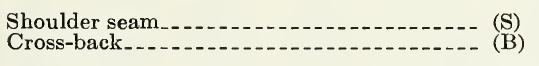 & $\begin{array}{r}33 / 4 \\
11 \frac{1}{8}\end{array}$ & $\begin{array}{r}37 / 8 \\
111 / 2\end{array}$ & $117 / 8$ & $\begin{array}{r}41 / 8 \\
121 / 4\end{array}$ & $\begin{array}{r}48 / 8 \\
12 \frac{3}{4}\end{array}$ & $\begin{array}{r}41 / 2 \\
131 / 4\end{array}$ \\
\hline
\end{tabular}

LENGTH MEASUREMENTS

\begin{tabular}{|c|c|c|c|c|c|c|}
\hline $\begin{array}{l}\text { Neck extension } \\
\text { Back waist. } \\
\text { Front waist } \\
\text { Waist to armscye } \\
\text { Waist to hip. } \\
\text { Total form }\end{array}$ & \begin{tabular}{c|}
3 \\
$111 / 8$ \\
$103 / 8$ \\
$53 / 4$ \\
$63 / 8$ \\
26
\end{tabular} & $\begin{array}{c}3 \\
111 / 2 \\
105 \% 8 \\
6 \\
65 / 8 \\
27\end{array}$ & \begin{tabular}{r|}
3 \\
$117 / 8$ \\
$107 / 8$ \\
$61 / 4$ \\
$67 / 8$ \\
$281 / 2$
\end{tabular} & \begin{tabular}{r|}
3 \\
$121 / 4$ \\
$111 / 8$ \\
$61 / 2$ \\
$71 / 8$ \\
$291 / 2$
\end{tabular} & \begin{tabular}{c|}
3 \\
$127 / 8$ \\
$115 / 8$ \\
$67 / 8$ \\
$71 / 2$ \\
31
\end{tabular} & $\begin{array}{l}3 \\
131 / 2 \\
121 / 8 \\
71 / 4 \\
77 / 8 \\
321 / 2\end{array}$ \\
\hline
\end{tabular}

1 This form is intended to be used for dresses, jackets, slips, blouses, etc., but not for coats. In drafting patterns the amount of tolerance over the form will vary according to the type of merchandise. For example, an undergarment should fit the form snugly while jackets should fit the form more loosely. 
TABLE 2. Girls' coat form measurements

\begin{tabular}{|c|c|c|c|c|c|c|}
\hline \multirow{2}{*}{ Name of measurement } & \multicolumn{6}{|c|}{$\mathrm{S} \mathrm{I} \mathrm{Z} \mathrm{E} \mathrm{S}$} \\
\hline & 7 & 8 & 9 & 10 & 12 & 14 \\
\hline \multicolumn{7}{|c|}{ GIRTH MEASUREMENTS } \\
\hline $\begin{array}{l}\text { Chest } \\
\text { Waist. } \\
\text { Heckline }\end{array}$ & \begin{tabular}{c|} 
Inches \\
$291 / 2$ \\
25 \\
30 \\
$115 / 8$
\end{tabular} & \begin{tabular}{c|} 
Inches \\
$301 / 1$ \\
$251 / 2$ \\
31 \\
12
\end{tabular} & $\begin{array}{l}\text { Inches } \\
311 / 2 \\
26 \\
32 \\
123 / 8\end{array}$ & \begin{tabular}{r|} 
Inches \\
$321 / 2$ \\
$261 / 2$ \\
$331 / 2$ \\
$123 / 4$
\end{tabular} & \begin{tabular}{c|} 
Inches \\
34 \\
$271 / 2$ \\
$351 / 2$ \\
$131 / 4$
\end{tabular} & $\begin{array}{r}\text { Inches } \\
351 / 2 \\
281 / 2 \\
371 / 2 \\
133 / 4\end{array}$ \\
\hline \multicolumn{7}{|c|}{ WIDTH MEASUREMENTS } \\
\hline $\begin{array}{l}\text { Shoulder seam } \\
\text { Cross-back } 1 \text { (B) }\end{array}$ & $\begin{array}{r}37 / 8 \\
113 / 8\end{array}$ & $\begin{array}{c}4 \\
113 / 4\end{array}$ & $\begin{array}{r}41 / 8 \\
121 / 8\end{array}$ & $\begin{array}{r}41 / 4 \\
121 / 2\end{array}$ & $13^{41 / 2}$ & $\begin{array}{r}45 / 8 \\
131 / 2\end{array}$ \\
\hline \multicolumn{7}{|c|}{ LENGTH MEASUREMENTS } \\
\hline $\begin{array}{l}\text { Neck extension } \\
\text { Back waist } \\
\text { Front waist. } \\
\text { Waist to armscye (E) } \\
\text { Waist to hip } \\
\text { Total form }\end{array}$ & $\begin{array}{c}3 \\
111 / 8 \\
103 / 8 \\
53 / 4 \\
6^{3} / 8 \\
26\end{array}$ & $\begin{array}{c}3 \\
111 / 2 \\
105 / 8 \\
6 \\
65 / 8 \\
27\end{array}$ & $\begin{array}{r}3 \\
117 / 8 \\
107 / 8 \\
61 / 4 \\
67 / 8 \\
281 / 2\end{array}$ & \begin{tabular}{r|r|}
3 \\
$121 / 4$ \\
$111 / 8$ \\
$61 / 2$ \\
$71 / 8$ \\
$291 / 2$
\end{tabular} & \begin{tabular}{c|}
3 \\
$127 / 8$ \\
$115 \% 8$ \\
$67 / 8$ \\
$71 / 2$ \\
31
\end{tabular} & $\begin{array}{r}3 \\
131 / 2 \\
121 / 8 \\
71 / 4 \\
77 / 8 \\
321 / 2\end{array}$ \\
\hline
\end{tabular}

TARLE 3. Girls' sports form ${ }^{1}$ measurements

\begin{tabular}{|c|c|c|c|c|c|c|}
\hline \multirow{2}{*}{ Name of measurement } & \multicolumn{6}{|c|}{ S I Z E S } \\
\hline & 7 & 8 & 9 & 10 & 12 & 14 \\
\hline \multicolumn{7}{|c|}{ GIRTH MEASUREMENTS } \\
\hline $\begin{array}{l}\text { Chest } \\
\text { Waist } \\
\text { Hip } \\
\text { Vertical trunk } \\
\text { Thigh } \\
\text { Knee } \\
\text { Calf (maximum) (C) } \\
\text { Neckline_... (W) }\end{array}$ & \begin{tabular}{c|} 
Inches \\
$271 / 2$ \\
23 \\
28 \\
$441 / 2$ \\
$15^{3} / 4$ \\
$105 / 8$ \\
$101 / 8$ \\
$113 / 8$
\end{tabular} & \begin{tabular}{c|} 
Inches \\
$281 / 2$ \\
$231 / 2$ \\
29 \\
46 \\
$161 / 2$ \\
$111 / 8$ \\
$105 / 8$ \\
$113 / 4$
\end{tabular} & $\begin{array}{c}\text { Inches } \\
291 / 2 \\
24 \\
30 \\
48 \\
173 / 8 \\
115 / 8 \\
111 / 8 \\
121 / 8\end{array}$ & $\begin{array}{l}\text { Inches } \\
301 / 2 \\
241 / 2 \\
311 / 2 \\
50 \\
181 / 4 \\
121 / 8 \\
1158 \\
121 / 2\end{array}$ & $\begin{array}{l}\text { Inches } \\
32 \\
251 / 2 \\
331 / 2 \\
521 / 2 \\
191 / 4 \\
125 / 8 \\
121 / 8 \\
13\end{array}$ & $\begin{array}{r}\text { Inches } \\
331 / 2 \\
261 / 2 \\
351 / 2 \\
55 \\
201 / 4 \\
131 / 8 \\
125 / 8 \\
131 / 2\end{array}$ \\
\hline
\end{tabular}

\section{WIDTH MEASUREMENTS}

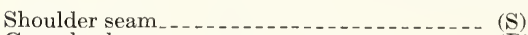

Cross-back ........................... (B)

\begin{tabular}{r|r|r|r|r|r}
$33 / 4$ & $37 / 8$ & 4 & $41 / 8$ & $43 / 8$ & $41 / 2$ \\
$111 / 8$ & $11 \frac{31}{2}$ & $117 / 8$ & $12 \frac{1}{4}$ & $123 / 4$ & $131 / 4$
\end{tabular}

\section{LENGTH MEASUREMENTS}



Back waist $\ldots \ldots \ldots$ (BL)

Front waist

Waist to armseye

Waist to hip.... (D)

Total crotch.......... (CL)

\begin{tabular}{c|c|}
3 & 3 \\
$111 / 8$ & $11 \frac{1}{2}$ \\
$103 / 8$ & $105 / 8$ \\
$53 / 4$ & 6 \\
$63 / 8$ & $65 / 8$ \\
22 & 23
\end{tabular}

3
$117 / 8$
$107 / 8$
$61 / 4$
$67 / 8$
24

3
$121 / 4$
$11 \frac{1}{8}$
$61 / 2$
$71 / 8$
25

\begin{tabular}{c|r}
3 & 3 \\
$127 / 8$ & $131 / 2$ \\
$115 / 8$ & $121 / 8$ \\
$67 / 8$ & $71 / 4$ \\
$71 / 2$ & $77 / 8$ \\
26 & $271 / 2$
\end{tabular}

VERTICAL MEASUREMENTS

Waist to knee $\ldots \ldots \ldots$ (G)

Crotch to knee..... (O)

Crotch to ankle.

Knee to ankle

\begin{tabular}{r|r|r|l|l|l}
$171 / 2$ & $183 / 8$ & $191 / 4$ & $201 / 8$ & $211 / 8$ & 22 \\
$83 / 4$ & $91 / 8$ & $95 \% 8$ & 10 & $103 / 8$ & $103 / 4$ \\
20 & 21 & 22 & 23 & 24 & 25 \\
$11 \frac{51}{4}$ & $117 / 8$ & $123 / 8$ & 13 & $135 / 8$ & $141 / 4$ \\
\hline
\end{tabular}

${ }_{1}$ This form is intended to be used for union suits, shorts, slacks, pajamas, etc. In drafting patterns the amount of tolerance over the form will vary according to the type of merchandise. For example, an undergarment should fit the form snugly, while pajamas should fit the form more loosely. 


\title{
EFFECTIVE DATE
}

16. Having been passed through the regular procedure of the Commodity Standards Division, and approved by the acceptors hereinafter listed, this commercial standard was issued by the United States Department of Commerce, effective from December 1, 1949.

\author{
Edwin W. Ely, \\ Chief, Commodity Standards Division.
}

\section{HISTORY OF PROJECT}

This standard was initiated in 1945 by the Limited Price Variety Stores Association, Inc., and the Mail Order Association of America, which requested the cooperation of the National Bureau of Standards in the development of a commercial standard for girls' model forms. It was felt that the use of standard sizes and measurements of model forms would assist in establishing, on a Nation-wide basis, the "height-weight" body measurement system of apparel sizing.

Following conferences with committees of the girls' apparel industryand with individual apparel distributors and model form manufacturers, a proposed standard, prepared by the proponent groups, was sent to representative manufacturers and users for advance comment. Some adjustments were made in the draft in the light of the comments received, after which the recommended standard was circulated to manufacturers, distributors and users of girls' model forms for consideration and acceptance.

On June 1, 1949, an announcement was issued that the standard had been accepted by a satisfactory majority of the model form industry, and approved for promulgation as Commercial Standard CS158-49.

\section{STANDING COMMITTEE}

The following individuals comprise the membership of the standing committee, which is to review, prior to circulation for acceptance, revisions proposed to keep the standard abreast of progress. Comment concerning the standard and suggestions for revision may be addressed to any member of the committee or to the Commodity Standards Division, National Bureau of Standards, which acts as secretary for the committee.

Miss O. L. Cantwell, Specifications Division, Sears, Roebuck \& Co., 360 West 31st Street, New York, N. Y. (chairman). (Representing Mail Order Association of America.)

JACOB J. Lubell, Schleifer \& Lubell, 520 8th Avenue, New York, N. Y. (Representing United Infants' \& Children's Wear Association.)

Joseph Martini, Cavanaugh Form Co., Inc., 832 Broadway, New York, N. Y.

John A. Mueller, Nazareth Mills, Inc., Nazareth, Pa. (Representing Underwear Institute.)

Mrs. Ernestine Kopp, Apparel Construction Division, Fashion Institute of Technology and Design. 225 West 24th Street, New York, N. Y.

Dr. A. Frank Tesi, W. T. Grant Co., 1441 Broadway, New York, N.Y. (Representing Limited Price Variety Stores Association, Inc.)

Samuel Weinstein, J. R. Bauman Normal Model Form Co., Inc., 134 West 26th Street, New York, N. Y.

Simon Wolf, Wolf Form Co., 140 Fifth Avenue, New York, N. Y. 


\section{ACCEPTANCE OF COMMERCIAL STANDARD}

If acceptance has not previously been filed, this sheet properly filled in, signed, and returned will provide for the recording of your organization as an acceptor of this commercial standard.

\section{Date}

Commodity Standards Division,

National Bureau of Standards,

Washington 25, D. C.

\section{Gentlemen :}

We believe that the Commercial Standard CS158-49 constitutes a useful standard of practice, and we individually plan to utilize it as far as practicable in the

$$
\text { production }^{1} \quad \text { distribution }^{1} \quad \text { purchase }^{1}
$$

of girls' model forms. We reserve the right to depart from it as we deem advisable.

We understand, of course, that only those articles which actually comply with the standard in all respects can be identified or labeled as conforming thereto.

Signature of authorized officer

$$
\text { (in ink) }
$$

(Kindly typewrite or print the following lines)

Name and title of above officer

Organization

Street address

City, zone, and State

1 Underscore which one. Please see that separate acceptances are filed for all subsidiary companies and affiliates which should be listed separately as acceptors. In the case of related interests, trade associations, trade papers, etc., desiring to record their general support, the words "General support" should be added after the signature. 


\section{TO THE ACCEPTOR}

The following statements answer the usual questions arising in connection with the acceptance and its significance:

1. Enforcement.-Commercial standards are commodity specifications voluntarily established by mutual consent of those concerned. They present a common basis of understanding between the producer, distributor, and consumer and should not be confused with any plan of governmental regulation or control. The United States Department of Commerce has no regulatory power in the enforcement of their provisions, but since they represent the will of the interested groups as a whole, their provisions through usage soon become established as trade customs, and are made effective through incorporation into sales contracts by means of labels, invoices and the like.

2. The acceptor's responsibility.-The purpose of commercial standards is to establish for specific commodities, nationally recognized grades or consumer criteria, and the benefits therefrom will be measurable in direct proportion to their general recognition and artual use. Instances will occur when it may be necessary to deviate from the standard and the signing of an acceptance does not preclude such departures; however, such signature indicates an intention to follow the commercial standard where practicable, in the production, distribution, or consumption of the article in question.

3. The Department's responsibility.-The major function performed by the Department of Commerce in the voluntary establishment of commercial standards on a Nation-wide basis is fourfold: first, to act as an unbiased coordinator to bring all interested parties together for the mutually satisfactory adjustment of trade standards; second, to supply such assistance and advice as past experience with similar programs may suggest; third, to canvass and record the extent of acceptance and adherence to the standard on the part of producers, distributors, and users; and fourth, after acceptance, to publish and promulgate the standard for the information and guidance of buyers and sellers of the commodity.

4. Announcement and promulgation.-When the standard has been endorsed by a satisfactory majority of production or consumption in the absence of active, valid opposition, the success of the project is announced. If, however, in the opinion of the standing committee or the Department of Commerce, the support of any standard is inadequate, the right is reserved to withhold promulgation and publication. 


\section{ACCEPTORS}

The organizations listed below have individually accepted this standard for use as far as practicable in the production, distribution, or use of model forms for girls' apparel. In accepting the standard, they reserved the right to depart from it as they individually deem advisable. It is expected that articles which actually comply with the requirements of this standard in all respects will be regularly identified or labeled as conforming thereto, and that purchasers will require such specific evidence of conformity.

\section{ASSOCIATIONS \\ (General Support)}

American Association of University Women, Georgia Division, Athens, Ga.

American Homemakers Association, Lorain, Ohio. Designers \& Patternmakers Guild, Philadelphia, Pa Limited Price Variety Stores Association, New York, N. Y.

Mail Order Association of America, Washington, D. C.

National Consumer-Retailer Council Inc., Plandome, Long Island, N. Y.

National Institute of Cleaning \& Dyeing, Silver Spring, Md.

New York State Federation of Women's Clubs, Plandome, Long Island, N. Y.

\section{FIRMS AND OTHER INTERESTS}

Adray Infants Creations, Inc., New York, N. Y. Alabama College, School of Home Economics, Montevallo, Ala.

Alabama Polytechnic Institute, Auburn, Ala.

Alaska, University of, Agricultural Extension Service, College, Alaska.

Albano, Robert, Inc., New York, N. Y.

Aldens, Inc., Chicago, Ill.

Apolda Mills, North Bergen, N. J.

Arizona State College, Flagstaff, Ariz.

Arizona, University of, School of Home Economics Tucson, Ariz.

Art-Rich Manufacturing Co., Dalton, Ga.

Asbury Mills, New York, N. Y. (General support.

Associated Merchandising Corp., New York, N. Y.

Baby Development Clinic, Chicago, Ill.

Banner Girl Coat Co., New York, N. Y.

Barg Togs, Inc., New York, N. Y.

Bauman, J. R., Normal Model Form, Inc., New York, N. Y.

Bayside Manufacturing Co., Inc., Fall River, Mass.

Bean, C. W., \& Son, Pacolet, S. C.

Beauty Pattern Co., Inc., New York, N. Y.

Becker, H., Co., Inc., New York, N. Y.

Benjamin, S. M., Model Form Corp., New York, N. Y

Better Fabrics Testing Bureau, Inc., New York, N. Y.

Bow Age, Inc., New York, N. Y.

Bradley University, Peoria, Ill. (General support.) Bradleys, Marysville, Calif

Brookdale Sport Togs, Inc., New York, N. Y.

Butler Bros., New York, N. Y.

Caltex Sportswear Co. of Calif., Inc., Los Angeles, Calif.

Carefree Sportswear, Los Angeles, Calif.

Carnegie Institute of Technology, Pittsburgh, Pa.

Carter \& Churchill Co., Lebanon, N. H.

Cash Wholesale Co., Little Rock, Ark.

Cavanaugh Form Co., Inc., New York, N. Y.

Cedar Crest College, Allentown, Pa. (General support.)

Central High School of Needle Trades, New York, N. Y

Central State College, Edmond, Okla.

Chambers Fischer Co., Bozeman, Mont.

Chelsea Sportswear, Inc., New York, N. Y.

Cogswell Corp., The, Newark, N. J.

Colorado, University of, Boulder, Colo.

Connecticut, University of, School of Home Economies, Storrs, Conn.

Corcoran, J. H., \& Co., Ine., Cambridge, Mass.
Cornell College, Mount Vernon, Iowa.

D \& C Stores, Inc., Stockbridge, Mich.

Dainty Manufacturing Co., Inc., New York, N. Y.

Davison-Paxon Co., Atlanta, Ga.

Deisroth's, P., Sons, Hazleton, Pa. (General support.)

Diane Co., Inc., Chicago, Ill.

Dixie Undergarment Co., New York, N. Y.

Durain, Jean, Los Angeles, Calif.

E-Cut Knitting Mills, Royersford, Pa.

East Texas State Teachers College, Commerce, Tex.

Evansville College, Evansville, Ind.

Fair, The, Chicago, Ill.

Fashion Academy, New York, N. Y

Fashion Institute of Technology \& Design, New York, N. Y. (General support.)

Fishman, M. H., Co., Inc., New York, N. Y.

Freedlander, H., Co., Wooster, Ohio.

Gault Bros., Ltd., Vancouver, British Columbia, Canada.

Gerla, H., New York, N. Y.

Gerry of California, Los Angeles, Calif.

Gilchrist Co., Boston, Mass.

Glamour Togs Co., Inc., New York, N. Y.

Globe Knitting Works, Grand Rapids, Mich.

Goodman, Al, Merchandising Corp., New York, N. Y.

Gorin's, Boston, Mass.

Grand Garment Manufacturing Co., Inc., St. Paul, Minn.

Grant, W. T., Co., New York, N. Y.

Green, H. L., Co., Inc., New York, N. Y.

Greenberg, Chas. S., Inc., New York, N. Y.

Hale Bros. Stores, Inc., San Francisco, Calif.

Half-Fare Frocks, St. Louis, Mo.

Halle Bros. Co., The, Cleveland, Ohio.

Handeraft Import Co., Inc., New York, N. Y.

Hatch Textile Research, New York, N.Y. (General support.)

Holliday, G. W., Ltd., Toronto, Ont., Canada.

Hollywood Garment Corp., Beverly Hills, Calif.

Holtsberg \& Bro., Inc., New York, N. Y.

Hospital Bureau of Standards \& Supplies, Inc., New York, N. Y.

Howick, W., Manufacturing Co., Ltd., Montreal, Quebec, Canada.

Hudson, J. L., Co., The, Detroit, Mich.

Iowa, State University of, Iowa City, Iowa.

Jabour Manufacturing Co., Los Angeles, Calif.

Jerry Coat Co., Inc., New York, N. Y.

Kansas State College, Manhattan, Kans.

Kansas Teachers College, Pittsburg, Kans. (General support.)

Kaufman, Isidor, New York, N. Y.

Kaufmann's Department Store, Inc., Pittsburgh, Pa.

Kay's Kiddie Shop, Alexandria, Va.

Kresge, S. S., Co., Detroit, Mich.

Kugelman's, Woodville, N. H.

Leda Sportwear, Inc., New York, N. Y.

Lee Manufacturing Co., San Gabriel, Calif.

Lee Sportswear Co., New York, N. Y.

Liman, M., Manufacturing Co., Minneapolis, Minn.

"Little Lady" Lingerie Co., Oakland, Calif.

Love, Joseph, Inc., New York, N. Y.

Lucky Girl Coat Co., Inc., Brookiyn, N. Y.

Lucky Star Undergarments, Inc., Brooklyn, N. Y.

Mabley \& Carew Co., The, Cincinnati, Ohio.

Maison Rouff, New York, N. Y.

Margulis Bros., St. Louis, Mo.

Markon Garment Co., Inc., Elizabeth, N. J. 
Mason, Sally, Inc., New York, N. Y.

May Fair Togs, Inc., New York, N. Y.

McCall Corp., New York, N. Y.

McCrory Stores Corp., New York, N. Y.

McKem Sales Corp., New York, N. Y.

Melcher \& Landau, Inc., Chicago, Ill.

Mellon Institute of Industrial Research, Pittsburgh, $\mathrm{Pa}$.

Michigan State College, East Lansing, Mich.

Miller Bros. Co., Rome, Ga.

Miller-Sinderman, Los Angeles, Calif.

Minnesota, University of, St. Paul, Minn.

Montana State University, Missoula, Mont.

Moore, Harry C., Dry Goods Co., Nevada, Mo.

Mormon Handicraft Gift Shop, Salt Lake City, Utah.

Moro Manufacturing Co., Inc., New York, N. Y.

New York Pattern Co., New York, N. Y.

Nonpareil Manufacturing Co., New York, N. Y.

O'Brien, Francis J., Co., Inc., New York, N. Y.

Ohio State University, School of Home Economics, Clothing \& Textiles Division, Columbus, Ohio.

Oklahoma A. \& M. College, Household Arts Department, Stillwater, Okla.

Onita Specialty Co., Inc., Brooklyn, N. Y.

Palace Store, The, Spokane, Wash.

Peerless Garment Co., Millville, N. J.

Peerless Pattern Co., New York, N. Y.

Plattsburg State Teachers College, Plattsburg, N.Y

Princess Togs, Inc., New York, N. Y. (General support.)

Quality Knitting Co., Inc., Stowe, $\mathrm{Pa}$.

Rauschenberg, G. H., Co., Inc., Dalton, Ga.

Reisman Rothman Corp., New York, N. Y.

Rike-Kumler Co., Dayton, Ohio.

Roosevelt Mills, Inc., Manchester, Conn.

Rose Sportwear, Inc, New York, N. Y.

Rossby, Inc., The, New York, N. Y.

Rudolph, J. H., \& Co., DeKalb, Ill.

Sachs, J. D., \& Co., Inc., New York, N. Y.

Sam Houston State Teachers College, Huntsville, Tex. (General support.)

Savage Manufacturing Co., Inc., Chicago, Ill.

Schleifer \& Lubell, New York, N. Y.

Schramm, J. S., Co., Burlington, Iowa.

Sears Roebuck \& Co., Chicago, Ill.

Shirley Cloak \& Dress Co., Atlanta, Ga.

Shuwall, E. \& E., Co., White Plains, N. Y.

Sibley, Lindsay \& Curr Co., Rochester, N. Y.

Solot, J., \& Taber Co., Inc., New York, N. Y.

Southern California, University of, Los Angeles, Calif. (General support.)
Southwest Texas State Teachers College, San Marcos, Tex.

Spiegel, Inc., Chicago, Ill.

Star Children's Dress Co., New York, N. Y.

Star Knitting Co., La Crosse, Wis.

Stephen F. Austin State Teachers College, Nacogdoches, Tex. (General support.)

Stout Institute, Menomonie, Wis.

Stratford Knitting Mills, Linfield, $\mathrm{Pa}$.

Strouss-Hirshberg's, Youngstown, Ohio.

Style Undies, Inc., New York. N. Y.

Sunnyside Apparel Co. of California, Los Angeles, Calif.

Syracuse University, College of Home Economics, Syracuse, N. Y.

Teentowner Coat Co., Kansas City, Mo.

Texas State College for Women, Denton, Tex.

Texas Technological College, Lubbock, Tex.

Texas, University of, Austin, Tex.

Textile Specialties Manufacturing Co., Windsor, Ontario, Canada.

Toledo, University of, Toledo, Ohio.

Topper Undergarment Co., New York, N. Y.

Tot-Wear Manufacturing Co., Inc., St. Paul, Minn. "Town-Girl" Wear, Ltd., Montreal, Quebec, Canada.

Trask, Prescott \& Richardson Co., Erie, Pa.

Trudy Little Dresses, Brooklyn, N. Y.

Tuttman, Louis, \& Son, Inc., New York, N. Y.

Undies, Inc., New York, N. Y.

United States Testing Co., Inc., Hoboken, N. J.

Upper Iowa University, Fayette, Iowa. (General support.)

Verlinda Frocks, Inc., New York, N. Y.

Vernon High School, Vernon, Tex.

Victory Girl Coat Co., Inc., New York, N. Y.

Virginia Polytechnic Institute, Blacksburg, Va. (General support.)

Weather-Rite Sportswear Co., Inc., New York, N. Y.

Weill, Charles, Inc., New York, N. Y.

West, O. B . Co Elizabeth City, N.C.

West Virginia University, Morgantown, W. Va.

Western Reserve University, Cleveland, Ohio. (General support.)

Whitner, C. K., Co., Inc., Reading, Pa.

Wichita University, Wichita, Kans.

Wieboldt Stores, Inc., Chicago, Ill.

Wolf Form Co., Inc., New York, N. Y.

Woolworth, F. W., Co., New York, N. Y.

Wyoming, University of, Laramie, Wyo. 


\section{COMMERCIAL STANDARDS}

CS No.

0-40. Commercial standards and their value to business (third edition).

1-42. Clinical thermometers (third edition).

2-30. Mopsticks.

3-40. Stoddard solvent (third edition).

4-29. Staple porcelain (all-clay) plumbing fixtures.

5-46. Pipe nipples; brass, copper, steel and wrought-iron (second edition).

6-31. Wrought-iron pipe nipples (second edition). Superseded by CS5-46.

7-29. Standard weight malleable iron or steel screwed unions.

8-41. Gage blanks (third edition).

9-33. Builders' template hardware (second edition).

10-29. Brass pipe nipples. Superseded by CS5-46.

11-41. Moisture regains of cotton yarns (second edition).

12-48. Fuel oils (sixth edition).

13-44. Dress patterns (fourth edition).

14-43. Boys' button-on waists, shirts, junior and sport shirts (made from woven fabrics) (third edition).

15-46. Men's pajama sizes (made from woven fabrics) (third edition).

16-29. Wall paper.

17-47. Diamond core drill fittings (fourth edition).

18-29. Hickory golf shafts.

19-32. Foundry patterns of wood (second edition)

20-47. Staple vitreous china plumbing fixtures (fourth edition)

21-39. Interchangeable ground-glass joints, stopcocks and stoppers (fourth edition).

22-40. Builders' hardware (nontemplate) (second edition).

23-30. Feldspar.

24-43. Screw threads and tap-drill sizes.

25-30. Special screw threads. Superseded by CS24-43.

26-30. Aromatic red cedar closet lining.

27-36. Mirrors (second edition).

28-46. Cotton fabric tents, tarpaulins and covers (second edition).

29-31. Staple seats for water-closet bowls.

30-31. Colors for sanitary ware. (Withdrawn as commercial standard, March 15, 1948.)

31-38. Wood shingles (fourth edition)

32-31. Cotton cloth for rubber and pyroxylin coating.

33-43. Knit underwear (exclusive of rayon) (second edition).

34-31. Bag, case, and strap leather.

35-47. Hardwood plywood (third edition).

36-33. Fourdrinier wire cloth (second edition).

$37-31$. Steel bone plates and screws.

38-32. Hospital rubber sheeting.

39-37. Wool and part wool blankets (second edition). (Withdrawn as commercial standard, July 14, 1941.)

40-32. Surgeons' rubber gloves.

41-32. Surgeons' latex gloves.

42-43. Structural fiber insulating board (third edition)

43-32. Grading of sulphonated oils.

44-32. Apple wraps.

45-48. Douglas fir plywood (eighth edition).

46-49. Hosiery lengths and sizes (fourth edition).

47-34. Marking of gold-filled and rolled-goldplate articles other than watchcases.

48-40. Domestic burners for Pennsylvania anthracite (underfeed type) (second edition).
CS No.

49-34. Chip board, laminated chip board, and miscellaneous boards for bookbinding purposes.

50-34. Binders board for bookbinding and other purposes.

51-35. Marking articles made of silver in combination with gold.

52-35. Mohair pile fabrics (100-percent mohair plain velvet, 100-percent mohair plain frieze, and 50-percent mohair plain frieze).

53-35. Colors and finishes for cast stone.

54-35. Mattresses for hospitals.

55-35. Mattresses for institutions.

56-49. Oak flooring (third edition).

57-40. Book cloths, buckrams, and impregnated fabrics for bookbinding purposes except library bindings (second edition).

58-36. Woven elastic fabrics for use in overalls (overall elastic webbing).

59-44. Textiles-testing and reporting (fourth edition).

60-48. Hardwood dimension lumber (second edition).

61-37. Wood-slat venetian blinds.

62-38. Colors for kitchen accessories.

63-38. Colors for bathroom accessories.

64-37. Walnut veneers.

65-43. Methods of analysis and of reporting fiber composition of textile products (second edition).

66-38. Marking of articles made wholly or in part of platinum.

67-38. Marking articles made of karat gold.

68-38. Liquid hypochlorite disinfectant, deodorant and germicide.

69-38. Pine oil disinfectant.

70-41. Phenolic disinfectant (emulsifying type) (second edition) (published with Cst1-

71-41. Phenolic disinfectant (soluble type) (second edition) (published with CS70-41).

72-38. Household insecticide (liquid spray type) 73-48. Old growth Douglas fir, Sitka spruce and Western hemlock standard stock doors (fourth edition)

74-39. Solid hardwood wall paneling.

75-42. Automatic mechanical draft oil burners designed for domestic installations (second edition)

76-39. Hardwood interior trim and molding.

77-48. Enameled cast iron plumbing fixtures (second edition).

78-40. Ground-and-polished lenses for sun glasses (second edition) (published with CS79$40)$.

79-40. Blown, drawn, and dropped lenses for sun glasses (second edition) (published with CS78-40).

80-41. Electric direction signal systems other than semaphore type for commercial and other vehicles subject to special motor vehicle laws (after market).

81-41. Adverse-weather lamps for vehicles (after market).

82-41. Inner-controlled spotlamps for vehicles (after market)

83-41. Clearance, marker, and identification lamps for vehicles (after market).

84-41. Electric tail lamps for vehicles (after market).

85-41. Electric license-plate lamps for vehicles (after market). 
CS No.

86-41. Electric stop lamps for vehicles (after market).

87-41. Red electric warning lanterns.

88-41. Liquid burning flares.

89-40. Hardwood stair treads and risers.

90- (Reserved for power shovels and cranes.)

91-41. Factory-fitted Douglas fir entrance doors.

92-41. Cedar, cypress and redwood tank stock lumber.

93-41. Portable electric drills (exclusive of high frequency).

94-41. Calking lead.

95-41. Lead pipe.

96-41. Lead traps and bends.

97-42. Electric supplementary driving and passing lamps for vehicles (after market).

98-42. Artists' oil paints.

99-42. Gas floor furnaces-gravity circulating type.

100-47. Porcelain-enameled steel utensils (third edition).

101-43. Flue-connected oil-burning space heaters equipped with vaporizing pot-type burners.

102- (Reserved for Diesel and fuel-oil engines.)

103-48. Rayon jacquard velour (with or without other decorative yarn) (second edition).

104-46. Warm-air furnaces equipped with vaporizing pot-type oil burners (second edition).

105-48. Mineral wool insulation for low temperatures (second edition).

106-44. Boys' pajama sizes (woven fabrics) (second edition)

107-45. Commercial electric-refrigeration condensing units (second edition). (Withdrawn as commercial standard September 4 , 1947.)

108-43. Treading automobile and truck tires.

109-44. Solid-fuel-burning forced-air furnaces.

110-43. Tire repairs - vulcanized (passenger, truck, and bus tires)

111-43. Earthenware (vitreous-glazed) plumbing fixtures.

112-43. Homogeneous fiber wallboard.

113-44. Oil-burning floor furnaces equipped with vaporizing pot-type burners.

114-43. Hospital sheeting for mattress protection.

115-44. Porcelain-enameled tanks for domestic use.

116-44. Bituminized-fibre drain and sewer pipe.

117-49. Mineral wool insulation for heated industrial equipment (second edition).

118-44. Marking of jewelry and novelties of silver.

(E) 119-45.1 Dial indicators (for linear measurements).

120-48. Standard stock ponderosa pine doors (third edition).

121-45. Women's slip sizes (woven fabrics).
CS No.

122-45. Western hemlock plywood.

123-45. Grading of diamond powder.

(E) 124-45.1 Master disks.

125-47. Prefabricated homes (second edition).

126-45. Tank mounted air compressors.

$127-45$. Self-contained mechanically refrigerated drinking water coolers.

128-45. Men's sport shirt sizes-woven fabrics (other than those marked with regular neckband sizes).

129-47. Materials for safety wearing apparel (second edition).

130-46. Color materials for art education in schools. 131-46. Industrial mineral wool products, all types-testing and reporting.

132-46. Hardware cloth.

133-46. Woven wire netting.

134-46. Cast aluminum cooking utensils (metal composition).

135-46. Men's shirt sizes (exclusive of work shirts)

136-46. Blankets for hospitals (wool, and wool and cotton).

137-46. Size measurements for men's and boys' shorts (woven fabrics).

138-47. Insect wire screening.

139-47. Work gloves.

140-47. Testing and rating convectors.

141-47. Sine bars, blocks, plates, and fixtures.

142-47. Automotive lifts.

143-47. Standard strength and extra strength perforated clay pipe.

144-47. Formed metal porcelain enameled sanitary ware.

145-47. Testing and rating hand-fired hot-watersupply boilers.

146-47. Gowns for hospital patients.

147-47. Colors for molded urea plastics.

148-48. Men's circular flat and rib knit rayon underwear.

149-48. Utility type house dress sizes.

150-48. Hot-rolled rail steel bars (produced from Tee-section rails)

151-48. Body measurements for the sizing of apparel for infants, babies, toddlers, and children (for the knit-underwear industry).

152-48. Copper naphthenate wood-preservative.

153-48. Body measurements for the sizing of apparel for girls (for the knit-underwear industry).

154- (Reserved for wire rope.)

155-49. Body measurements for the sizing of apparel for boys (for the knit-underwear industry).

156-49. Colors for polystyrene plastics.

157-49. Ponderosa pine and sugar pine plywood.

158-49. Model forms for girls' apparel.

1 Where " $(\mathrm{E})$ " precedes the CS number, it indicates an emergency commercial standard, drafted under war conditions with a view toward early revision.

NoтісE-Those interested in commercial standards with a view toward accepting them as a basis of everyday practice may secure copies of the above standards, while the supply lasts, by addressing the Commodity Standards Division, National Bureau of Standards, Washington 25, D. C. 